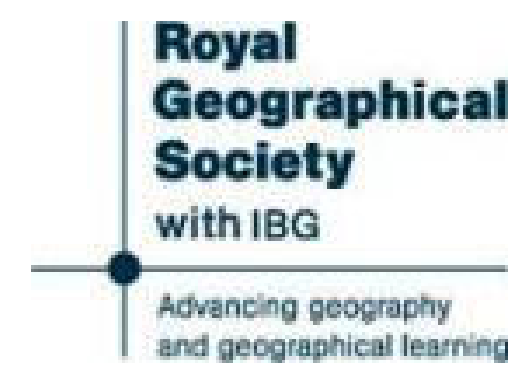

\title{
Speculative Ethnology
}

The Origin of the Bantu: A Preliminary Study by I. F. van Oordt

Review by: H. H. Johnston

The Geographical Journal, Vol. 30, No. 2 (Aug., 1907), pp. 202-203

Published by: The Royal Geographical Society (with the Institute of British Geographers)

Stable URL: http://www.jstor.org/stable/1776633

Accessed: 18/01/2015 09:55

Your use of the JSTOR archive indicates your acceptance of the Terms \& Conditions of Use, available at

http://www.jstor.org/page/info/about/policies/terms.jsp

JSTOR is a not-for-profit service that helps scholars, researchers, and students discover, use, and build upon a wide range of content in a trusted digital archive. We use information technology and tools to increase productivity and facilitate new forms of scholarship. For more information about JSTOR, please contact support@jstor.org. 
method being that recommended by the Historical Manuscripts Commission. The documents have a very living interest, and show in a vivid manner the troubles and difficulties of the early traders, not only with the native rulers, but also with the other European trading companies, especially in connection with the attempt made by Sir Thomas Roe to revive the Red sea trade. Mr. Foster bas added a useful introduction, in which he condenses the history of these three years, giving references to the original documents printed in the body of the book. The work, which must have been a laborious task, is well done, and Mr. Foster has laid under a debt of gratitude all persons working at the history of our early occupation of India.

\section{The Santal Parganas.}

'The Story of an Indian Upland.' By F. B. Bradley-Birt, B.A., I.c.s. London :

Smith Elder. 1905. Size $9 \times 5 \frac{1}{2}$, pp. xiv. and 354. Price 128. $6 d$. net.

Mr. Bradley-Birt, who is already well known by his book on Chota Nagpur, has in this volume undertaken the task of describing one of the most interesting districts of India, the Santal Parganas, and he has met with great success. Fascinated with the glamour of the East, and writing in a fluent and easy style, Mr. Bradley-Birt has produced a most vivid and entertaining narrative.

Where the Ganges takes its big southerly bend rise the Rajmahal hills, and in these hills live an aboriginal Dravidian people-the Paharias. Pushed by pressure from the west until they were brought to a stand in what has been called this cul de sac, the Paharias have dwelt for centuries among these mountain fastnesses, supporting themselves by raiding the plains, and from their hills have seen the Hindu and Mussulman empires wax and wane, leaving them uncontaminated and untamed. It was not until the advent of the British Raj that they were brought into some subjection, and the change was due to the genius of a young Englishman, Augustus Cleveland. Cleveland, who had a rare sympathy with the people, and who was only twenty-nine when he died, so arranged matters that the Paharias were left in possession of their hills, and a district at the foot, the Daman-i-koh, was also assigned to them. But the Paharias were afraid to leave their homes, and consequently these spurs of the hills were left unoccupied until the coming of the Santals, another aboriginal people, who, with a perfect genius for agriculture, soon turned what had been waste jungle into smiling fields.

Such are the people of whom Mr. Bradley-Birt writes, of their mode of life, their religion, their feasts and ceremonies, and he also adds a chapter on Deoghar, the sacred city of the Hindus, the home of Siva. The book is a model of what such books should be-a vivid narrative, well written, and full of sympathy for the subject with which it deals.

\section{AFRICA.}

Speculative Ethnology.

'The Origin of the Bantu : a Preliminary Study.' By I. F. van Oordt, B.A. Cape Town: Official Publication of the Cape Government. 1907.

Mr. van Oordt argues in this work that the Bantu languages owe their origin to the invasion-to two invasions (in about 1300 B.c. and 680 B.c.)-of North-East Africa by a "Sumerian" people from Mesopotamia, who introduced a "Ugro-Altaic" type of language into Negro Africa; in fact, the mother tongue of the Bantu. The Hottentots, Mr. van Oordt contends, are related anciently, not only in race but in language, with the Negrito Semang of the Malay peninsula. The Semang and the Sakai he believes to be related in language with the MouAnnam, the 'libetan, Dravidian, and Ugro-Altaic peoples. The first of his 
Bantu invasions (placed by him theoretically in about 1300 в.c.) brought into North-East Africa a Dravidian rather than an "Ugro-Altaic" element (linguistically), though, as the one (in his opinion) is fundamentally related to the other, this fact does not modify his general conclusion (p. 24), that the Bantu languages and those of the Ugro-Altaic race sprang from one common stock some 7000 years ago. (Mr. van Oordt elsewhere suggests that the immediate ancestors of the Bantu did not enter Africa, when they came "by sea," till about 3200 years ago; but several of his statements are mutually contradictory.)

Not content with this bold thesis, he carries his readers on to the "Malacca peninsula," where he believes "we shall find the origin of the Bantu." He then gives a comparative table of eight pages to show the supposed resemblances between word-roots in Semang, Sakai, and Jakun (Skeat and Blagden are his authorities for these citations), and roots of similar meaning in Bantu languages. Also other tables to show correspondence between roots in Hottentot and Semang; between Bantu and Dravidian tongues; and between Shuna (of Mashonaland) and Assyrian.

It is sufficient to say that these tables prove nothing, certainly lend no weight to Mr. van Oordt's speculations; do not, for example, prove that there is any marked resemblance or connection in syntax or word-roots between any set of Asiatic languages (except the half-African Semitic) and any group of African tongues, such as there is-marvellous to relate-between the Malagasy dialects and the speech of Polynesia. It is this staggering fact of the colonization of Madagascar from Sumatra or Java, across the Indian ocean, without contact with Africa, that alone excuses such wild theorizing as that of Mr. van Oordt. But he can give no proof to satisfy a trained philologist that the Bantu languages came from Asia, or that Hottentots and the Negritos of the Malay peninsula (after possibly a hundred thousand years of divergence from a common centre of origin) still maintain any linguistic connection. It should be added that the Bantu words and their etymologies quoted in this work are often misleading. Mr. van Oordt persistently mixes up the separable, changeable Bantu prefix with the actual word-root; and he cites, by some misapprehension, words which do not exist, or words borrowed from Arabic or Portuguese.

Incidentally, his bluebook is interesting because of the large number of Bantu languages illustrated (and some of them quite correctly), but it is a dangerous work for the uninitiated. It is disagreeable to have to write thus disparagingly of an Afrikander's work in African philology. I can only hope that Mr. van Oordt, so far from being discouraged by criticism, will take advantage of his position and residence in South Africa to give himself up to detail work, which is badly needed. Let him undertake researches into Shi-shuna, into the dialectal differences of the Kafir speech, into the North Kalahari language-field or the scarcely known idiom of the Berg Damara. Then the present writer will be amongst the readiest to thank him.

The fact is, it is sheer waste of time speculating on the non-African origin of the Bantu languages. This group is as much African as the Fula, Mandingo, lower Niger, Nyamnyam, and Nilotic language-families, with which it possesses features of fundamental relationship. What we now want from National South Africa is sound, first-hand research, not useless theorizing : work like that accomplished by Sir George Grey, Dr. Livingstone, W. G. Palgrave, F. W. Kolbe, and Dr. W. H. T. Bleek; and of late by the French, Swiss, and London Missionary Societies' pastors in South Africa.

H. H. Johsston. 